\title{
Characterization and anti-uterine tumor effect of extract from Prunella vulgaris L.
}

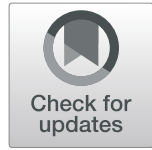

Yan Lin ${ }^{1 \dagger}$, Chao Yang ${ }^{1 \dagger}$, Jie Tang ${ }^{1}$, Chun Li², Zhi-min Zhang ${ }^{1}$, Bo-hou Xia', Ya-mei Li', Qing-zhi He³ ${ }^{3}$ Li-mei Lin ${ }^{1}$ and Duan-fang Liao ${ }^{1 *}$

\begin{abstract}
Background: The flowers and dried fruit spikes of Prunella vulgaris L. (P. vulgaris L.) have been widely used in traditional Chinese medicine and food. P. vulgaris $L$. is regarded as a good option for treating uterine myoma (UM). However, scientific evidence of anti-UM activity of the extract of $P$. vulgaris L. (PVE) is lacking. The present study aimed to characterize the chemical composition of PVE and evaluate the pharmacodynamics and mechanism of PVE against UM.

Methods: The chemical composition of PVE was analyzed by GC-MS. MTT was used to screen and evaluate cell proliferation and toxicity. Double fluorescence flow cytometry method were used to determine the apoptosis and cell cycle progression of UM cells under PVE treatment. The anti-UM activity of PVE was investigated by using a specific-pathogen-free (SPF) rat model of UM. TUNEL staining was used to detect the apoptosis of UM cells. The concentrations of estrogen and progesterone in the serum of SPF rats were detected by ELISA. The expression levels of PCNA, estrogen receptor alpha, estrogen receptor beta, progesterone receptor, survivin, caspase-3, Bax and $\mathrm{BCl}-2$ in the uterus of SPF rats was detected by immunohistochemistry (IHC).

Results: The extraction rate of PVE was $8.1 \%$. The main components were squalene (28.3\%), linoleic acid (9.96\%), linolenic acid (9.95\%), stearic acid (6.26\%) and oleic acid (5.51\%). In vitro, PVE had significant anti-human UM cell activity, exhibited no drug toxicity, promoted the apoptosis of human UM cells, and inhibited the transition of UM cells from the G0/G1 stage into the G2 stage, in which DNA replication occurs. In vivo, PVE had significant anti-UM activity. PVE decreased the concentrations of estrogen and progesterone and downregulated the expression levels of the estrogen and progesterone receptors through the estrogen signaling pathway. PVE also promoted the apoptosis of UM cells by downregulating the expression levels of the survivin and Bcl-2 proteins and upregulating the expression levels of caspase-3 and Bax through the mitochondria-mediated apoptotic pathway.
\end{abstract}

Conclusion: PVE has marked anti-UM activity. PVE can be used as an ideal candidate drug to treat UM.

Keywords: Prunella vulgaris L., Uterine Myoma, GC-MS, Apoptosis

\footnotetext{
* Correspondence: dfliao@hnucm.edu.cn

${ }^{\dagger}$ Yan Lin and Chao Yang contributed equally to this work.

'Key Laboratory for Quality Evaluation of Bulk Herbs of Hunan Province,

College of Pharmacy, Hunan University of Chinese Medicine, No.300 Xueshi

Road, Changsha 410208, People's Republic of China

Full list of author information is available at the end of the article
}

(C) The Author(s). 2020 Open Access This article is licensed under a Creative Commons Attribution 4.0 International License, which permits use, sharing, adaptation, distribution and reproduction in any medium or format, as long as you give appropriate credit to the original author(s) and the source, provide a link to the Creative Commons licence, and indicate if changes were made. The images or other third party material in this article are included in the article's Creative Commons licence, unless indicated otherwise in a credit line to the material. If material is not included in the article's Creative Commons licence and your intended use is not permitted by statutory regulation or exceeds the permitted use, you will need to obtain permission directly from the copyright holder. To view a copy of this licence, visit http://creativecommons.org/licenses/by/4.0/ The Creative Commons Public Domain Dedication waiver (http://creativecommons.org/publicdomain/zero/1.0/) applies to the data made available in this article, unless otherwise stated in a credit line to the data. 


\section{Background}

Uterine myoma (UM) is the most frequent benign tumor in women and is responsible for menorrhagia, other forms of abnormal uterine bleeding, iron deficiency anemia, and urinary incontinence [1]. The pathogenesis of UM may be related to sex hormones and their receptors, cell proliferation and apoptosis, abnormal signal transduction pathways, molecular genetics and other factors [2, 3]. The tumor growth rate of UM is associated with the estrogen signaling pathway [4]. Estrogen and progesterone can directly or indirectly affect the growth and development of UM [5]. Estrogen and progesterone can regulate the expression of the growth factors of UM [6, 7]. The inhibitory effects of estrogen and progesterone on UM tumor growth are mainly mediated by suppressing the expression levels of the receptors of these hormones [8]. The apoptosis of UM cells is associated with the mitochondria-mediated apoptotic pathway, which shifts the balance in the Bcl-2 family toward the proapoptotic members, such as Bax [9]. Bcl-2 protein located on mitochondrial membranes suppressed the release of apoptogenic proteins from mitochondria to the cytosol. Mitochondria-mediated apoptosis is also mediated by the activation of Bax, which results in an increase in caspase-3 [10]. The intrinsic mitochondriamediated apoptotic pathway is also triggered by downregulating $\mathrm{Bcl}-2$ protein expression, which activates caspase-3, the final executioner of apoptosis [11]. UM is commonly treated by corticosteroids, which are associated with a high recurrence rate and marked side effects, and by hormone therapy, which induces substantial pain [12]. Traditional Chinese Medicine has a definite advantage in curing UM [13].

The flowers and dried fruit spikes of Prunella vulgaris L. (P. vulgaris L.) have been widely used in traditional Chinese medicine and food. This plant has antitumor, anti-inflammatory, antiviral, antioxidant, and antibacterial functions [14]. Moreover, $P$. vulgaris L. is regarded as a good option for treating constipation, mammary gland hyperplasia, hysteromyoma, oophoritis cysts and breast cancer [15-17]. It is rich in essential oil, triterpenes and polysaccharide constituents. The essential oil of this plant has an inhibitory effect on the proliferation of cervical cancer and breast cancer cells [18-20]. Triterpenes have an inhibitory effect on the proliferation of breast cancer cells and can inhibit the estrogen receptor signaling pathway [21-23]. Polysaccharides have an inhibitory effect on the proliferation of breast cancer cells and can induce apoptosis [24].

In our previous research, we found that among the extract of $P$. vulgaris L. obtained by supercritical fluid $\left(\mathrm{CO}_{2}\right)$ extraction and its triterpene and polysaccharide fractions, the extract was most effective for treating UM. The triterpenes were the most effective fraction for treating breast cancer, and the polysaccharides were the most effective fraction for the treatment of lipid disorders. Therefore, in the present study, the extract of Prunella vulgaris L. (PVE) was extracted by supercritical fluid $\left(\mathrm{CO}_{2}\right)$ extraction and characterized by GC-MS, and its effects against UM and the underlying mechanisms were investigated. We investigated, for the first time, the effects of PVE on the growth and apoptosis of UM cells. The apoptotic cell death of UM induced by PVE was confirmed in vitro by the MTT method and double fluorescence flow cytometry method and in vivo by hematoxylin and eosin (HE) staining, TUNEL staining, ELISA, and immunohistochemistry (IHC).

\section{Methods}

\section{Plant material}

Flowers and dried fruit spikes of $P$. vulgaris $L$. were purchased in Anhui province and confirmed as $P$. vulgaris $L$. by Limin Gong, an Associate Professor in the Pharmacy Teaching Department at the Hunan University of Chinese Medicine.

\section{Cells}

Human uterine smooth muscle cells (HUSMCs) and human uterine myoma cells (HUMCs) (SK-UT-1) were purchased from the Cell Bank of the Chinese Academy of Science (Shanghai, China).

\section{Antibodies and reagents}

The proliferating cell nuclear antigen (PCNA) kit, TUNEL kit, caspase-3 antibody, Bax antibody, Bcl-2 antibody, survivin antibody, estrogen receptor alpha (ER- $\alpha)$ kit, estrogen receptor beta (ER- $\beta$ ) kit, progesterone receptor (PR) kit, estrogen kit, progesterone kit, and HE stain used in this study were purchased from Beijing Biosynthesis Biotechnology Co., Ltd. (Beijing, China). Progesterone, Gong Liu-qing capsule (GLC), estradiol benzoate, and mifepristone (MF) were purchased from the First Hospital of Hunan University of Chinese Medicine (Changsha, China). 3-(4,5-Dimethyl-2-thiazolyl)-2, 5-diphenyl-tetra-zolium bromide (MTT) was purchased from Sigma Chemical Company (St. Louis, USA), and Dulbecco's modified Eagle's medium (DMEM) was purchased from HyClone (Logan, UT, USA). Fetal bovine serum (FBS) was purchased from Gibco Company (Grand Island, NY, USA). An apoptosis kit and cell cycle kit were purchased from Multi Sciences (Lianke) Biotech, Co., Ltd. (Hangzhou, China).

\section{Preparation and analysis of PVE}

PVE was extracted for $120 \mathrm{~min}$ at $25 \mathrm{MPa}$ and $30^{\circ} \mathrm{C}$ by supercritical fluid $\left(\mathrm{CO}_{2}\right)$ extraction. One milliliter of PVE was accurately measured and dissolved in ethyl acetate to a final volume of $10 \mathrm{ml}$ in a volumetric flask. 
PVE components were determined by GC-MS. A DB-5MS quartz capillary column $(30 \mathrm{~m} \times 0.25 \mathrm{~mm} \times 0.25 \mu \mathrm{m}$, Agilent J\&W Scientific, Folsom, USA) was used. The injector temperature was set to $280^{\circ} \mathrm{C}$. A total of $1 \mu$ of sample was injected, with a split ratio of 1:1. The flow rate of helium carrier gas $(99.999 \%)$ was set to $1.0 \mathrm{ml} / \mathrm{min}$. The temperature was first set at $100^{\circ} \mathrm{C}$, held for $2 \mathrm{~min}$, gradually increased at a column temperature rate of $5{ }^{\circ} \mathrm{C} / \mathrm{min}$ to $270^{\circ} \mathrm{C}$ and held for $5 \mathrm{~min}$. The temperate of the electron ionization source was $200^{\circ} \mathrm{C}$. The solvent delay duration was $6.5 \mathrm{~min}$, and the MS scanning range was $35-550 \mathrm{~m} / \mathrm{z}$. The chromatograms were subjected to ion-pair extraction, peak alignment, peak matching, and peak amplitude correction using NISTOS and NISTOSs.

\section{Cell experiments}

Toxicity evaluation of HUSMCs and HUMCs

HUSMCs and HUMCs in the logarithmic growth phase were separately plated in 96-well plates at a density of $1.0 \times 10^{4}$ cells/well. The edge wells were filled with sterile PBS. The cells were cultured at $37^{\circ} \mathrm{C}$ in a $5 \% \mathrm{CO}_{2}$ atmosphere for $24 \mathrm{~h}$. The culture medium in the wells was discarded, and the cells were treated with a PVE concentration of 1.0, 2.0, 3.0, 4.0, 5.0, 6.0, 7.0 or $8.0 \mathrm{mg} /$ $\mathrm{ml}$ and a GLC concentration of 1.0, 2.0, 3.0, 4.0, 5.0, 6.0, $7.0,8.0$ or $9.0 \mathrm{mg} / \mathrm{ml}$. A negative control group and a positive control group were included in parallel. Each concentration was represented in five parallel wells. After stimulating the cells with the appropriate drugs for $24 \mathrm{~h}$, the culture medium was discarded. Next, $100 \mu \mathrm{l}$ of $0.5 \mathrm{mg} / \mathrm{ml} \mathrm{MTT}$ was added to each well, and the cells were incubated for $4 \mathrm{~h}$. The culture medium was discarded, and $150 \mu \mathrm{l}$ of DMSO was added to each well and incubated for $10 \mathrm{~min}$ on a horizontal shaker. When the violet crystals were completely dissolved, the absorbance at $490 \mathrm{~nm}\left(\mathrm{~A}_{490}\right)$ was measured using a microplate reader (Thermo Electron Corporation, USA). The rates of cell growth inhibition and the IC50 were then calculated.

\section{Detection of apoptosis and cell cycle in HUMCs}

HUMCs in the logarithmic growth phase were seeded into 6 culture flasks at a density of $5.0 \times 10^{5}$ cells/well. The cells were cultured at $37^{\circ} \mathrm{C}$ in a $5 \% \mathrm{CO}_{2}$ atmosphere for $24 \mathrm{~h}$. The culture medium in the wells was then discarded. Subsequently, the cells were washed twice with PBS and treated with $5 \mathrm{ml} P V E$ at a concentration of $0.65(0.25 \times \mathrm{IC} 50), 1.30(0.50 \times \mathrm{IC} 50), 1.95$ $(0.75 \times \mathrm{IC} 50)$, or $2.60 \mathrm{mg} / \mathrm{ml}(1.0 \times \mathrm{IC} 50)$ and GLC at a concentration of $4.65 \mathrm{mg} / \mathrm{ml}$. After stimulating the cells with the drugs for $24 \mathrm{~h}$, the cells were centrifuged at $1000 \mathrm{rpm}$ for $3 \mathrm{~min}$. The culture medium was then discarded. Next, the cells were washed twice with PBS, centrifuged, and collected. The cells were suspended in
Annexin V buffer solution, and $5 \mu \mathrm{l}$ of each of Annexin V-FITC and propidium iodide (PI) was added to each well. The cells were then incubated for $15 \mathrm{~min}$ in the dark. The cell cycle was measured by double fluorescence flow cytometry.

\section{Animal experiment \\ Animal}

Specific-pathogen-free (SPF) female rats $(200 \pm 20 \mathrm{~g})$ were purchased from Hunan SJA Laboratory Animal Co., Ltd. (Changsha, China). The animal permit number was SCXK (Xiang) 2016-0002. The temperature and humidity used for animal housing met the requirements for housing experimental animals. The rats were maintained under a $12 \mathrm{~h}$ dark-light cycle and were acclimated for 1 week prior to the experiment. Animal care and treatments were conducted according to guidelines and protocols approved by the Animal Care and Use Committee of the University of Hunan University of Chinese Medicine (Changsha, China). All efforts were made to minimize the number of animals and their suffering.

\section{Model construction and pharmacological intervention}

A total of 70 rats were randomly divided into the following 7 groups ( $n=10$ per group): control group (C); model group (M); GLC positive control group (GLC, an antiprogesterone drug, has been widely used to treat $\mathrm{UM}, 0.30 \mathrm{~g} / \mathrm{kg}$ [25]); mifepristone positive control group (mifepristone has been widely used to treat UM, $5.4 \mathrm{mg}$ / kg [26]); and low-, medium-, and high-dose PVE groups (LPVE $(0.11 \mathrm{~g} / \mathrm{kg})$, MPVE $(0.22 \mathrm{~g} / \mathrm{kg})$, and HPVE $(0.44 \mathrm{~g} /$ $\mathrm{kg}$ ), respectively). The control group was treated with normal saline by oral gavage, and the other groups were treated with estradiol benzoate injection $(0.4 \mathrm{mg})$ and progesterone injection $(0.2 \mathrm{mg})$ every other day for 60 days [27]. After the model establishment, the control and model groups were treated with normal saline by oral gavage, and the other groups were treated with the indicated medicine by oral gavage. Oral administration was carried out every morning for 30 days. At the end of the treatment, rats were injected with a high concentration of pentobarbital sodium $(80 \mathrm{mg} / \mathrm{kg})$ for anesthesia, blood was collected from the abdominal aorta, and cervical dislocation was performed. The uteri were collected and weighed. Serum samples were prepared by centrifuging the collected blood samples (at $2000 \mathrm{rpm}$ for 10 min at $4{ }^{\circ} \mathrm{C}$ ) and then stored at $-80^{\circ} \mathrm{C}$.

\section{HE staining of UM}

The uterine tissue samples were fixed in $10 \%$ formalin. Then, the paraffin-embedded tissue samples were sectioned into $5 \mu \mathrm{m}$-thick slices. The sections were stained with $\mathrm{HE}$ and examined under a light microscope (Model IX71, Olympus, Tokyo, Japan). 


\section{Detection of estrogen and progesterone}

To detect the effect of PVE on estrogen content following estradiol benzoate and progesterone treatment, the concentrations of estrogen in the serum samples were detected by using the estrogen ELISA Kits (Beijing Biosynthesis Biotechnology Co., Beijing, China) according to the mamufacture's instructions. The concentrations of estrogen were calculated from a standard curve and the results are expressd in $\mathrm{pg} / \mathrm{ml}$. To detect the effect of PVE on progesterone content, the serum concentrations of progesterone were detected by using the progesterone ELISA Kits (Beijing Biosynthesis Biotechnology Co., Beijing, China) according to the mamufacture's instructions. The concentrations of progesterone were calculated from a standard curve and the results are expressd in $\mathrm{ng} / \mathrm{ml}$.

\section{Detection of apoptosis in UM}

Uterine tissue samples were collected, and the extent of cell apoptosis in the UM was measured using the TUNEL kit. The cell apoptosis assay stained in the green channel. DAPI was applied as a nuclear counter-stain in the blue channel. Images were taken with light microscopy. The TUNEL assay figures were analyzed by ImagePro Plus (version 6.0) software (Media Cybernetics Inc., Maryland, USA). TUNEL-positive cells were considered to be undergoing apoptosis. The proportion of apoptotic uterine tissue was determined by dividing the number of TUNEL-positive nuclei by the total number of nuclei.

\section{IHC of UM}

Antibodies against PCNA, caspase-3, Bax, Bcl-2, survivin, ER- $\alpha, E R-\beta$ and PR were used to detect the expression levels of PCNA, caspase-3, Bax, Bcl-2, survivin, ER- $\alpha$, ER$\beta$ and PR in uterine tissues through IHC. The proportion of positive expression in uterine tissue was determined by dividing the number of positive cells by the total number of cells.

\section{Statistical analysis}

The data were represented as mean $\pm \mathrm{SD}$ and analyzed by SPSS 13.0 software (SPSS Inc., Chicago, USA). Student's $t$-test was used for comparisons between groups. One-way analysis of variance (ANOVA) was used for comparisons among groups. Nonparametric data were analyzed by Mann-Whitney $\mathrm{U}$ test. $p<0.05$ was considered statistically significant.

\section{Results}

Chemical composition of PVE

The extraction rate of PVE achieved by the supercritical fluid $\left(\mathrm{CO}_{2}\right)$ extraction kit was $8.1 \%$. Sixteen components were identified in PVE by GC-MS. The major constituents were squalene (28.03\%), linoleic acid (9.96\%), $\alpha$-linolenic acid (9.95\%), octadecanoic acid (6.26\%), and oleic acid (5.51\%) (Table 1).

\section{Toxicity evaluation in HUSMCs and HUMCs}

The toxicities of PVE and GLC to HUSMCs were assessed by MTT staining. HUSMCs were treated with various concentrations of PVE and GLC. Toxicity curves were constructed with concentration on the $\mathrm{X}$-axis and inhibition rate on the $\mathrm{Y}$-axis and are shown in Fig. 1a-b. In HUSMCs, the IC50 of PVE was $4.58 \mathrm{mg} / \mathrm{ml}$, whereas GLC did not show any toxicity. In HUMCs, the IC50 of

Table 1 The composition of the extract in Prunella vulgaris L.

\begin{tabular}{|c|c|c|c|c|c|c|}
\hline No & $t_{R}(\min )$ & Compouds & Chemical formula & Relative molecular mass & Relative contents (\%) & Similarity $(\%)$ \\
\hline 1 & 4.762 & m-Dimethylbenzene & $\mathrm{C}_{8} \mathrm{H}_{10}$ & 106 & 0.14 & 98 \\
\hline 2 & 9.613 & D-Limonene & $\mathrm{C}_{10} \mathrm{H}_{16}$ & 136 & 0.13 & 96 \\
\hline 3 & 26.268 & 2-Hydroxy-4-methoxy acetophenone & $\mathrm{C}_{9} \mathrm{H}_{10} \mathrm{O}_{3}$ & 166 & 1.07 & 98 \\
\hline 4 & 28.802 & Pentadecane & $\mathrm{C}_{15} \mathrm{H}_{32}$ & 212 & 0.19 & 94 \\
\hline 5 & 32.537 & Hexadecane & $\mathrm{C}_{16} \mathrm{H}_{34}$ & 226 & 0.19 & 96 \\
\hline 6 & 36.103 & Heptadecane & $\mathrm{C}_{17} \mathrm{H}_{36}$ & 240 & 0.53 & 97 \\
\hline 7 & 42.759 & n-Heneicosane & $\mathrm{C}_{21} \mathrm{H}_{44}$ & 296 & 0.48 & 96 \\
\hline 8 & 45.670 & Palmitic acid & $\mathrm{C}_{16} \mathrm{H}_{32} \mathrm{O}_{2}$ & 256 & 2.37 & 93 \\
\hline 9 & 51.184 & Linoleic acid & $\mathrm{C}_{18} \mathrm{H}_{32} \mathrm{O}_{2}$ & 280 & 9.96 & 89 \\
\hline 10 & 51.450 & a-Linolenic acid & $\mathrm{C}_{18} \mathrm{H}_{30} \mathrm{O}_{2}$ & 278 & 9.95 & 90 \\
\hline 11 & 51.570 & Oleic Acid & $\mathrm{C}_{18} \mathrm{H}_{34} \mathrm{O}_{2}$ & 282 & 5.51 & 93 \\
\hline 12 & 51.837 & Octadecanoic acid & $\mathrm{C}_{18} \mathrm{H}_{36} \mathrm{O}_{2}$ & 284 & 6.26 & 94 \\
\hline 13 & 56.450 & Arachidic acid & $\mathrm{C}_{20} \mathrm{H}_{40} \mathrm{O}_{2}$ & 312 & 2.71 & 91 \\
\hline 14 & 60.310 & 1,2-Benzenedicarboxylic acid & $\mathrm{C}_{24} \mathrm{H}_{38} \mathrm{O}_{4}$ & 390 & 2.76 & 96 \\
\hline 15 & 67.367 & Squalene & $\mathrm{C}_{30} \mathrm{H}_{50}$ & 410 & 28.03 & 95 \\
\hline 16 & 70.237 & n-Tetratriacontane & $\mathrm{C}_{34} \mathrm{H}_{70}$ & 478 & 2.15 & 94 \\
\hline
\end{tabular}



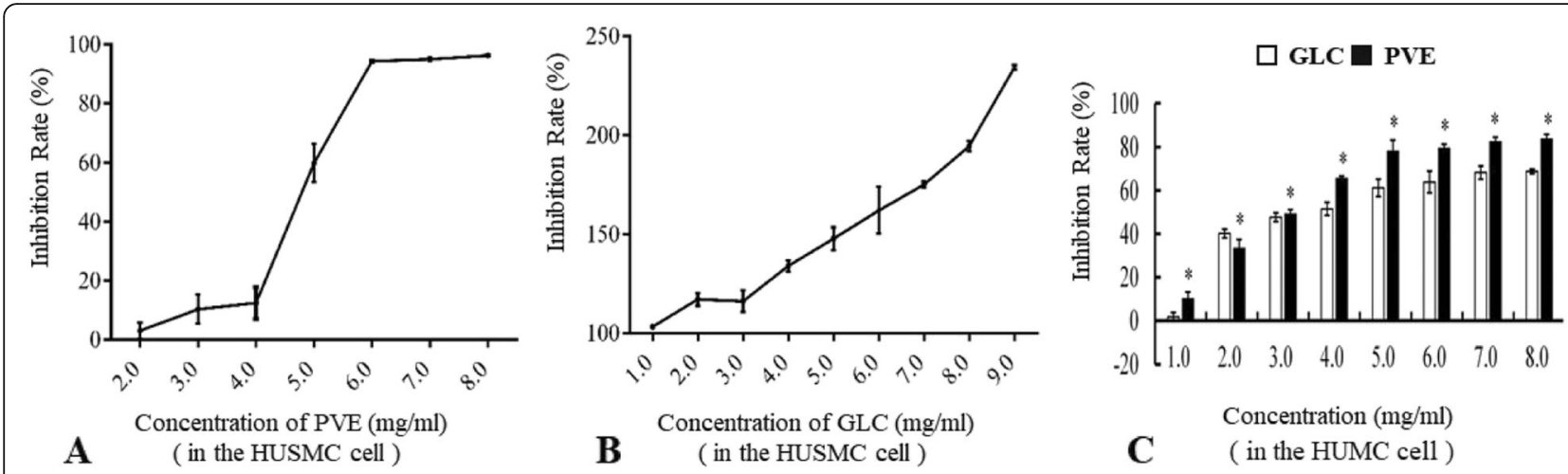

Fig. 1 Inhibition rates of PVE and GLC by MTT assay. a: Inhibition rates of treatment with varying PVE concentrations of 2.0, 3.0, 4.0, 5.0, 6.0, 7.0 or $8.0 \mathrm{mg} / \mathrm{ml}$ at $24 \mathrm{~h}$ in the HUSMC cells; b: Inhibition rates of treatment with varying GLC concentrations of 1.0, 2.0, 3.0, 4.0, 5.0, 6.0, 7.0, 8.0 or 9.0 $\mathrm{mg} / \mathrm{ml}$ at $24 \mathrm{~h}$ in the HUSMC cells; c: Inhibition rates of treatment with varying PVE or GLC concentrations of 1.0, 2.0, 3.0, 4.0, 5.0, 6.0, 7.0 or 8.0 $\mathrm{mg} / \mathrm{ml}$ at $24 \mathrm{~h}$ in the HUMC cells, compared with the GLC group, ${ }^{*} p<0.05$

PVE was $2.60 \mathrm{mg} / \mathrm{ml}$, while the IC50 of GLC was 4.65 $\mathrm{mg} / \mathrm{ml}$. The inhibitory rate increased with PVE concentration. Moreover, the inhibition of proliferation induced by PVE was significantly increased compared with that induced by the positive control drug (GLC) $(p<0.05)$ (Fig. 1c).

\section{Detection of apoptosis and cell cycle in HUMCs}

Because the IC50 of PVE in HUSMCs was $4.58 \mathrm{mg} / \mathrm{ml}$ and GLC did not show any toxicity, the apoptosis of HUMCs induced by PVE and GLC was assessed only by double fluorescence flow cytometry method. The percentage of apoptotic cells was $57.40 \%$ with PVE treatment and $52.91 \%$ with GLC treatment (Fig. 2a-b). These results indicated that cell apoptosis occurred. Compared with the model group, the PVE treatment groups and GLC treatment group exhibited significantly inhibited proliferation $(p<0.05)$, demonstrating that treatments with different concentrations of PVE and treatment with GLC had inhibitory effects. The GLC and PVE $(1.0 \times$ IC50) treatments had comparable effects. The cell cycle was detected in the different groups (Fig. 2c). The time in the G0/G1 phase increased with increasing PVE concentration. In addition, the cell cycle of HUMCs treated with PVE was arrested at the G0/G1 stage. Thus, the proliferation of HUMCs was inhibited at the G2 stage, precluding DNA synthesis (Table 2).

\section{Detection of UM weights}

UM weight was significantly different between the model group and control group $(p<0.05)$. In addition, UM weight was significantly different between the model group and each of the groups treated with GLC; mifepristone; and high, medium, and low doses of PVE $(p<0.05)$, indicating that these drugs can inhibit the growth of UM (Table 3, Fig. 3a-b). The GLC-treated group, mifepristone-treated group, high-dose PVE-treated group, and the medium-dose PVE-treated group exhibited similar extents of inhibited UM growth.

\section{HE staining of UM}

As shown in Fig. 3c, uterine swelling, uterine mass, hemorrhagic damage, and uterine retention were increased in the model group compared with the control group. Moreover, compared with the control group, the model group exhibited increased proliferation of endometrial epithelial cells, elongated and enlarged uterine smooth muscle, and increased eosinophils. These results showed that the UM model was successfully established. Compared with the model group, the groups treated with GLC, mifepristone, and a high dose of PVE showed improved histological appearance, as evidenced by decreasing uterine damage and reduced or absent edema. The uterus returned to the normal condition with PVE treatment. The results showed that PVE at a high dose can be used to successfully treat UM (Fig. 3c).

\section{Detection of estrogen and progesterone in serum}

As shown in Fig. 4, the estrogen and progesterone concentrations were significantly increased in the model group, compared with the control group. These results also showed that the UM model was successfully established. Compared with the model group, the estrogen concentrations of the serum in the GLC; mifepristone; and high-, medium-, and low- doses of PVE groups were significantly decreased and returned to control levels. Compared with the model group, the progesterone concentrations of the serum were significantly decreased in the high-dose PVE-treated group. These results indicated that the high-dose PVE could decrease the concentrations of estrogen and progesterone. 


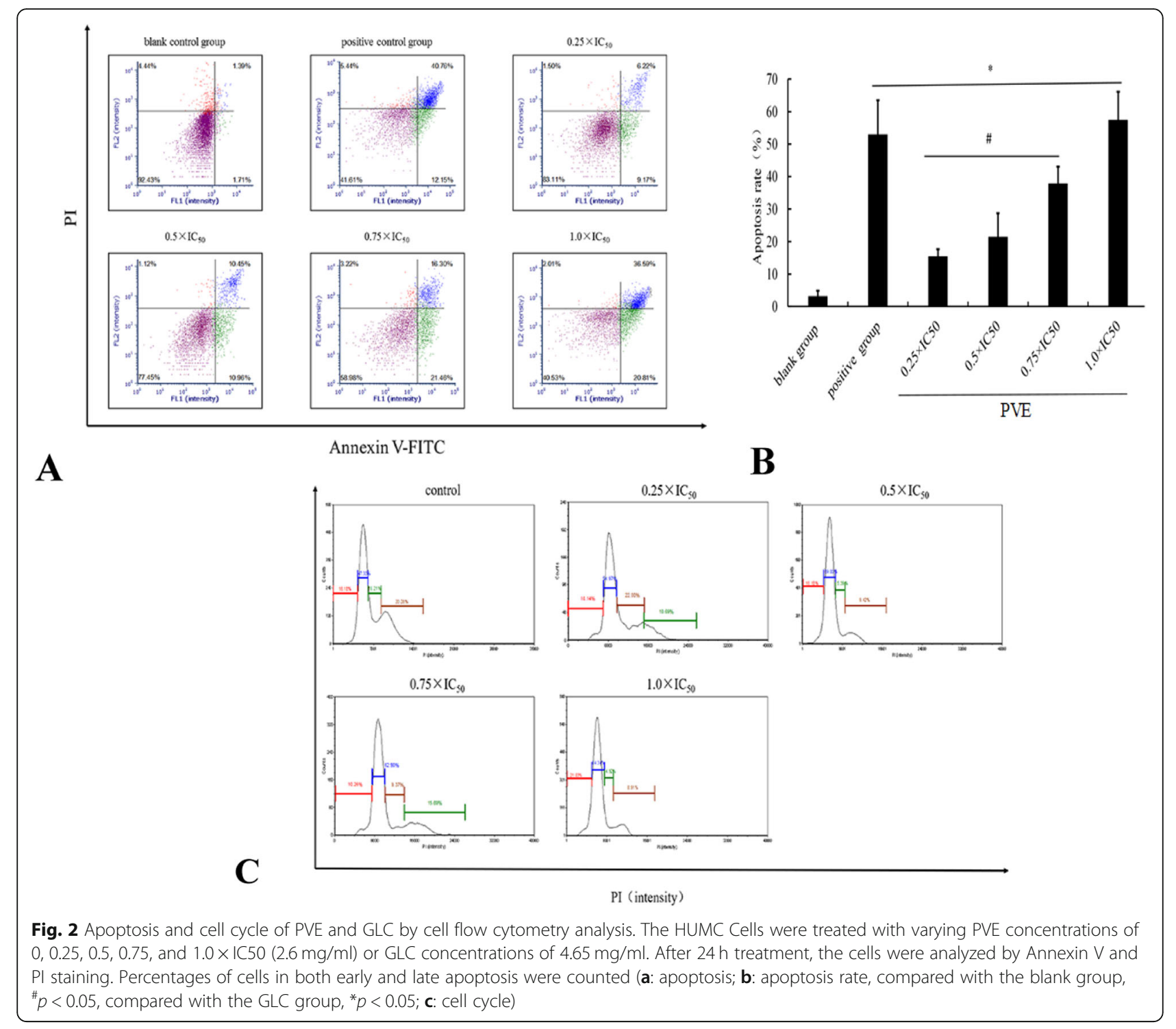

Table 2 Cell cycle distribution treated with PVE at different concentrations in the HUMC cell

\begin{tabular}{|c|c|c|c|c|}
\hline Cell cycle & Concentration & Cell cycle distribution & & \\
\hline \multirow[t]{5}{*}{ G0-G1 } & 0 & $47.33 \%$ & \multirow{2}{*}{\multicolumn{2}{|c|}{$\begin{array}{l}\text { Table } 3 \text { Tumor suppressor rate of the rats in the different } \\
\text { groups }\end{array}$}} \\
\hline & $0.25 \times 1 C_{50}$ & $54.97 \%$ & & \\
\hline & $0.5 \times I C_{50}$ & $62.90 \%$ & Group & Tumor suppressor rate(\%) \\
\hline & $0.75 \times 1 \mathrm{I}_{50}$ & $64.34 \%$ & Control & / \\
\hline & $1.0 \times I C_{50}$ & $69.00 \%$ & Model & / \\
\hline \multirow[t]{5}{*}{ G2 } & 0 & $20.28 \%$ & GLC & 84.32 \\
\hline & $0.25 \times 1 C_{50}$ & $15.69 \%$ & Mifepristone & 81.94 \\
\hline & $0.5 \times 1 C_{50}$ & $10.69 \%$ & Low-dose PVE & 49.80 \\
\hline & $0.75 \times I C_{50}$ & $8.91 \%$ & Medium-dose PVE & 66.72 \\
\hline & $1.0 \times I_{50}$ & $9.42 \%$ & High-dose PVE & 80.04 \\
\hline
\end{tabular}




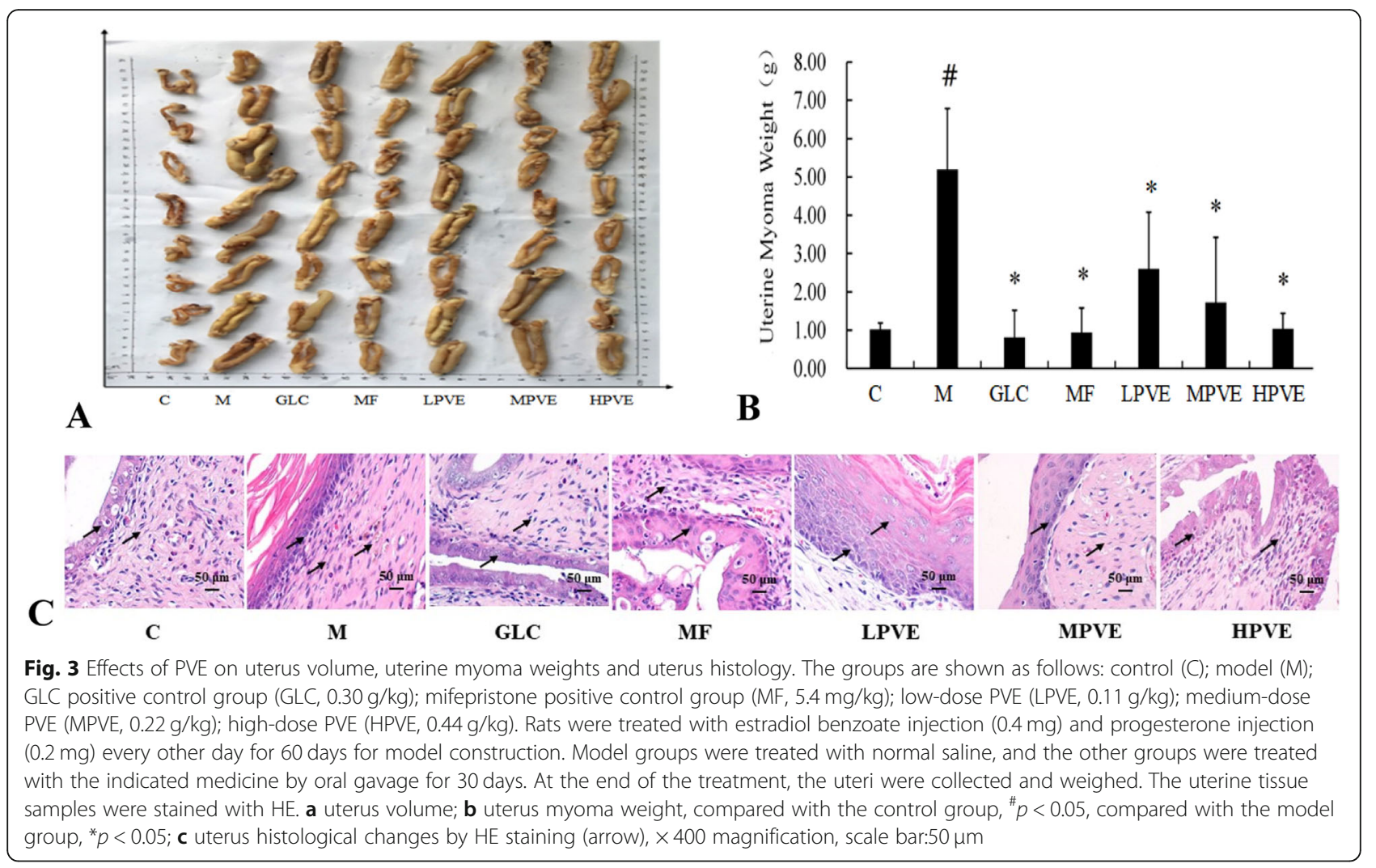

\section{Detection of apoptosis in UM}

The apoptosis in UM was detected by TUNEL staining. As shown in Fig. 5a, greater TUNEL-positive cells in the uterus tissue were found in GLC and PVE treatment groups compared to the model group. As shown in Fig. 5b, the apoptosis index were also significantly increased in GLC and PVE treatment groups compared to the model group. The apoptosis index were increased in high-, and mediadoses PVE treatment groups compared to the GLC group. The apoptosis index in PVE treatment groups increased

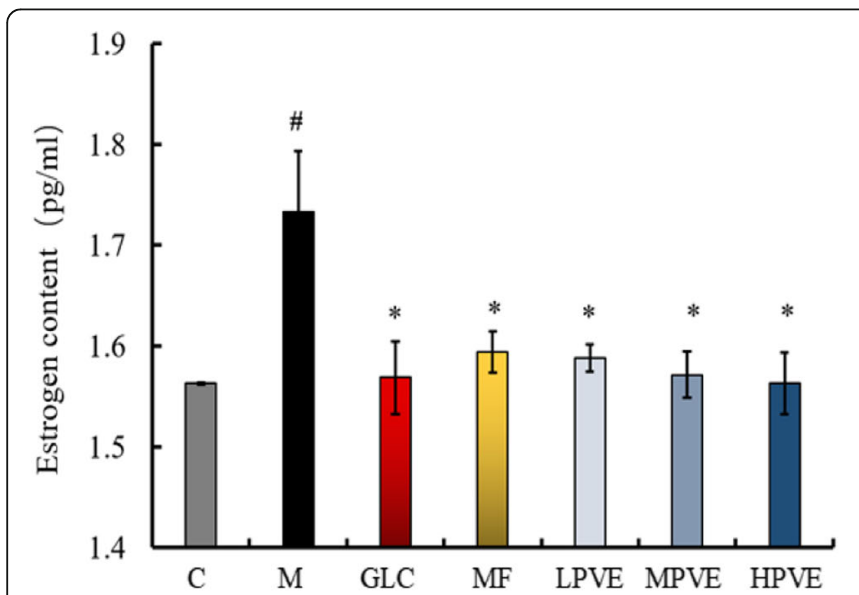

A

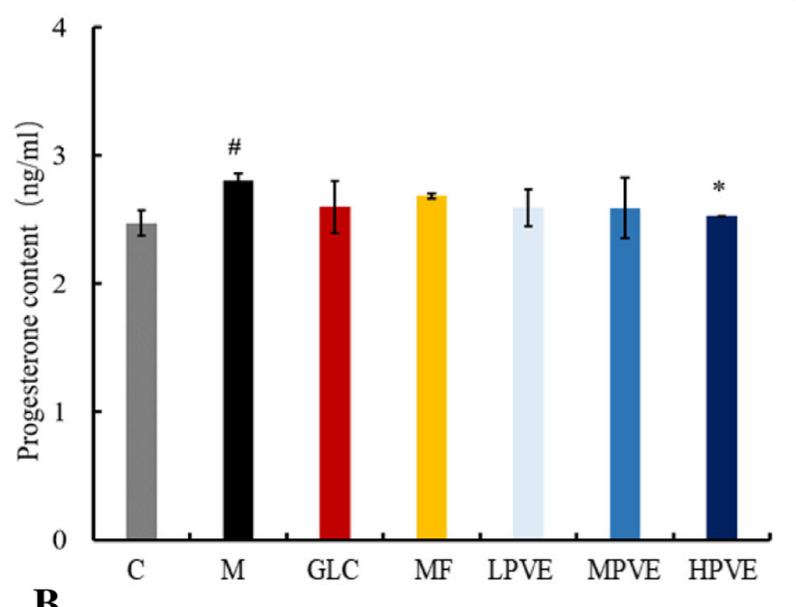

Fig. 4 Effects of PVE on estrogen and progesterone content following estradiol benzoate and progesterone treatment. The groups are shown as follows: control (C); model (M); GLC positive control group (GLC, $0.30 \mathrm{~g} / \mathrm{kg}$ ); mifepristone positive control group (MF, $5.4 \mathrm{mg} / \mathrm{kg}$ ); low-dose PVE (LPVE, $0.11 \mathrm{~g} / \mathrm{kg}$ ); medium-dose PVE (MPVE, $0.22 \mathrm{~g} / \mathrm{kg}$ ); high-dose PVE (HPVE, $0.44 \mathrm{~g} / \mathrm{kg}$ ). a: the content of estrogen detected in the serum by the estrogen ELISA Kits; $\mathbf{b}$ : the content of progesterone detected in the serum by the progesterone ELISA Kits; compared with the control group, ${ }^{\#} p<0.05$; compared with the model group, ${ }^{*} p<0.05$ ) 

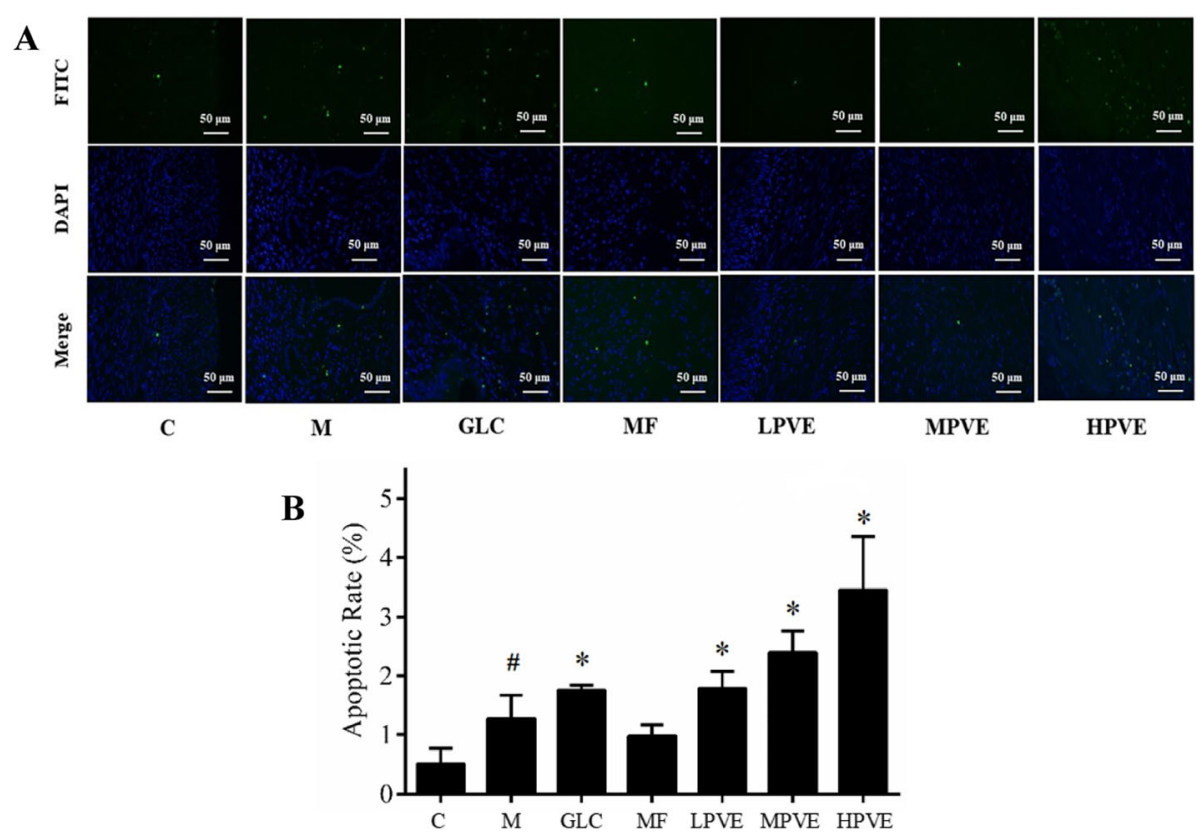

Fig. 5 Effects of PVE on apoptosis of the uterus tissue by TUNEL staining. The groups are shown as follows: control (C); model (M); GLC positive control group (GLC, $0.30 \mathrm{~g} / \mathrm{kg}$ ); mifepristone positive control group (MF, $5.4 \mathrm{mg} / \mathrm{kg}$ ); low-dose PVE (LPVE, $0.11 \mathrm{~g} / \mathrm{kg}$ ); medium-dose PVE (MPVE, $0.22 \mathrm{~g} / \mathrm{kg}$ ); high-dose PVE (HPVE, $0.44 \mathrm{~g} / \mathrm{kg}$ ). a: TUNEL staining merged figures, TUNEL (green) staining: the cell apoptosis assay stained in the green channel, DAPI (blue) staining: DAPI was applied as a nuclear counter-stain in the blue channel, $\times 400$ magnification, scale bar:50 $\mu$ m; $\mathbf{b}$ : apoptotic rate, compared with the normal group, ${ }^{*} p<0.05$; compared with the model group, ${ }^{*} p<0.05$

with increasing PVE concentration. These results indicated that PVE could promote the apoptosis of UM cells.

\section{IHC of UM}

Compared with the control group, the model group showed significantly different expression levels of PCNA, PR, ER- $\alpha$, ER- $\beta$, survivin, Bcl-2, caspase-3, and Bax $(p<0.05)$. The expression levels of PCNA, PR, ER- $\alpha$, ER- $\beta$, survivin, and Bcl-2 were downregulated to normal levels after treatment with PVE, while caspase- 3 and Bax were upregulated to normal levels after treatment with PVE at the medium and high concentrations. Compared with the model group, the positive control group and the high-dose PVE treatment group showed significant differences in the expression levels of PCNA, PR, ER- $\alpha$, ER- $\beta$, survivin, caspase-3, Bax and $\mathrm{Bcl}-2(p<0.05)$. These results suggest that PVE may induce apoptosis through the downregulation of PCNA, PR, ER- $\alpha, E R-\beta$, survivin, and Bcl-2 and the upregulation of caspase-3 and Bax (Fig. 6a-i).

\section{Discussion}

In this study, PVE was extracted by supercritical fluid $\left(\mathrm{CO}_{2}\right)$ extraction with high extraction efficiency and without negative environmental effects. Parameters, such as temperature, pressure and time, that affect the extraction efficiency of PVE, were discussed and optimized by orthogonal testing. Under the optimal conditions, the extraction rate of PVE was $8.1 \%$. Sixteen components, which composed less than $50 \%$ of the PVE, were identified by GC-MS. The remaining components of PVE await identification in the future.

Apoptosis is the process of programmed cell death and is generally characterized by distinct changes in morphology and biochemical mechanisms in cells. Apoptosis involves the exposure of phosphatidylserine secondary messengers to the membrane and DNA fragmentation [28]. To confirm the mechanism of PVE-induced UM cell death, flow cytometry analysis was conducted. Early or late apoptosis and DNA damage were detected by Annexin V/PI staining and a PI labeling assay, respectively. The early apoptosis rate of HUMCs treated with PVE (36.59\%) was higher than that of the control HUMCs (10.45\%). In addition, the late apoptosis rate of HUMCs treated with PVE (20.81\%) was higher than that of the control HUMCs (1.71\%). PVE induced dose-dependent increases in the total apoptosis rate and decreased the survival rate (Fig. 2).

The cell cycle is closely related to cell proliferation and death, and cell cycle arrest has been used as an indicator of the anticancer activity of a drug. The G1 phase, a stage that occurs before $S$ phase, prepares the cell for division and DNA synthesis [29]. Progression through the cell cycle is controlled by cell cycle checkpoints, i.e., G1, S, G2 and M, and depends on the action of cyclins, cyclin-dependent kinases (CDKs) and cyclin-dependent kinase inhibitors (CDKIs) [30]. Tranilast was found to arrest the proliferation of UM cells at the G0/G1 phase 
A
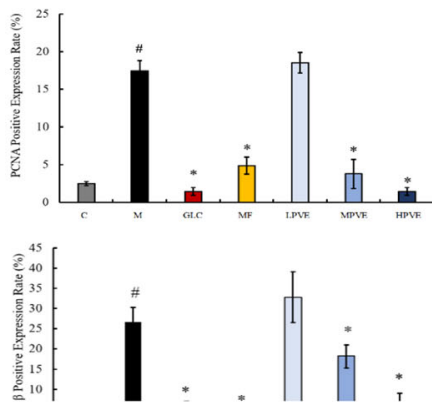

C

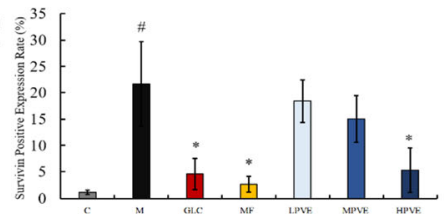

E

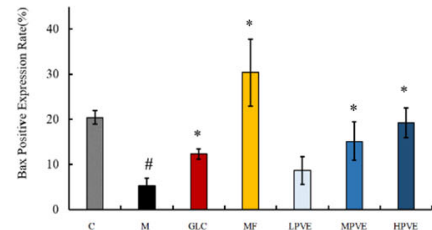

G

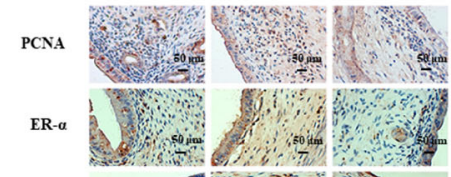

D

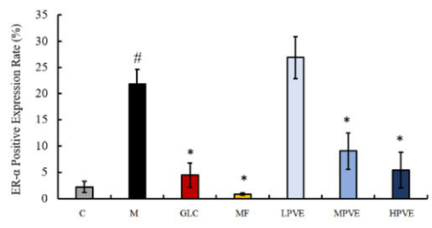

B
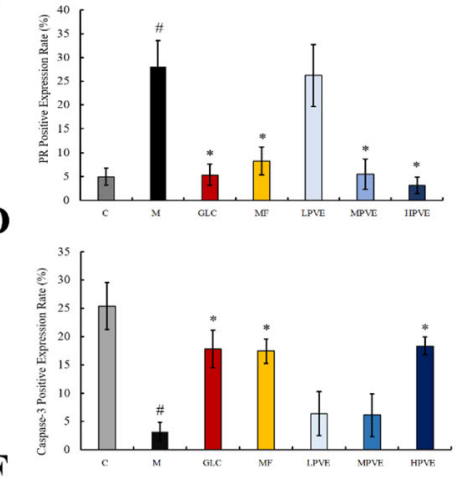

H

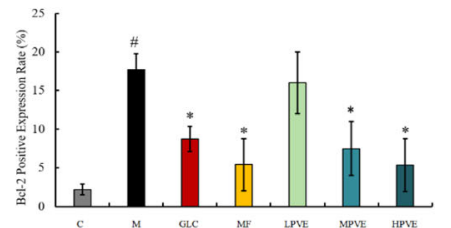

ER-P

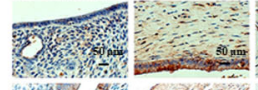

PR
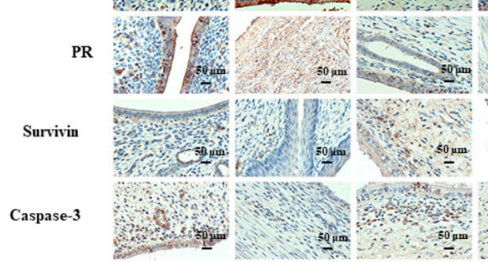

1.:
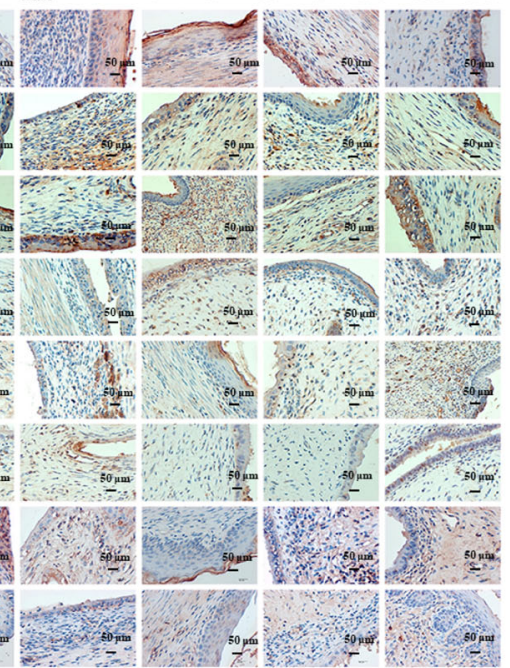

MF

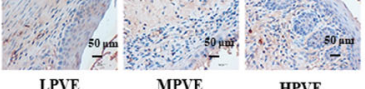

Fig. 6 Effects of PVE on positive expression levels of PCNA, ER-a, ER- $\beta$, PR, Survivin, Caspase-3, Bax and BCl-2. The groups are shown as follows: control (C); model (M); GLC positive control group (GLC, $0.30 \mathrm{~g} / \mathrm{kg}$ ); mifepristone positive control group (MF, $5.4 \mathrm{mg} / \mathrm{kg}$ ); low-dose PVE (LPVE, $0.11 \mathrm{~g} / \mathrm{kg}$ ); medium-dose PVE (MPVE, 0.22 g/kg); high-dose PVE (HPVE, $0.44 \mathrm{~g} / \mathrm{kg}$ ). a-h: positive expression rate of PCNA, ER-a, ER- $\beta$, PR, Survivin, Caspase-3, Bax, and Bcl-2 in the uterus tissue under PVE treatment by $\mathrm{IHC}$; Compared with the control group, ${ }^{\sharp} P<0.05$; Compared with the model group, ${ }^{*} p<0.05$; i: IHC images of PCNA, ER- $a$, ER- $\beta$, PR, Survivin, Caspase-3, Bax, and BCl-2 in the uterus tissue under PVE treatment by $\mathrm{HC}, \times 400$ magnification, scale bar:50 $\mu \mathrm{m}$ )

through the suppression of CDK2 activity via an induction of p21 $1^{\text {waf1 }}$ and p53 [31]. Growth inhibition and G0/G1 arrest of the cell cycle in NIH3T3 cells was found to be associated with the upregulation of p27 expression and progesterone receptor $\beta$ [32]. $\beta$-Hydroxyisovalerylshikonininduced apoptosis resulted in an accumulation of the endometriotic stromal cells in the G0/G1 phase of the cell cycle, with a concomitant decrease in the proportion of cells in $\mathrm{S}$ phase [33]. The G0/G1 cell population is considered to be an indicator of growth suppression that reflects cell cycle inhibition. In this study, as shown in Table 2, the percentage of cells in G0/G1 stage was higher under PVE treatment than under control treatment. PVE concentration had an effect on G2 phase opposite that observed on G0/ G1 phase. These results indicated that PVE promoted the apoptosis of HUMCs, inhibited the proliferation of HUMCs 
in the G0/G1 stage, and prevented cell entry into the G2 stage for DNA replication, consistent with previous studies. However, further studies was necessary to clarify the the mechanism of PVE-treated UM, which was related to cyclins, cyclin-dependent kinases (CDKs) and cyclin-dependent.

In addition to the increased levels of endogenous and exogenous components in the model group, the incidence of UM was increased in this group. Estrogen and progesterone can promote the proliferation of UM cells. Accordingly, UM has been treated by decreasing the levels of endogenous estrogen and progesterone [34, 35]. In this study, PVE downregulated the levels of estrogen and progesterone in UM, which returned to normal levels (Fig. 4). The apoptosis index was significantly increased in the group treated with the high dose of PVE compared with the model group. These results showed that PVE can induce UM apoptosis. Cyclin PCNA may be related to tumor cell proliferation. Apparent deregulation of PCNA with increased expression in tissues adjacent to tumors has been observed in some breast tumors [36]. The decrease in PCNA expression in PVEtreated UM suggested that the reduction in UM size due to the decreased number of cycling cells was mediated through reductions of ER and PR. The potential mechanism by which PVE inhibits tumor cell proliferation in $\mathrm{UM}$ is through decreases in the contents of estrogen and progesterone and downregulation of ER and PR expression through the estrogen signaling pathway.

Bcl-2, which has antiapoptotic properties, is associated with the outer mitochondrial membrane. Bcl-2 stabilizes membrane permeability, thereby preserving mitochondrial integrity, suppressing the release of cytochrome $\mathrm{c}$ and inhibiting apoptosis [37]. The $\mathrm{Bcl}-2$ family proteins are the central regulators of mitochondria-mediated apoptosis and are commonly classified into two groups: antiapoptotic members, such as Bcl-2, and proapoptotic members, such as Bax [38]. Our results suggest that PVE may trigger an intrinsic mitochondria-mediated apoptotic pathway by downregulating Bcl-2 expression and upregulating Bax. Survivin is a recently discovered mammalian inhibitor of apoptosis protein and can inhibit Bax-mediated apoptosis. Survivin can inhibit caspase 3 directly and indirectly and thereby prevent apoptosis. Caspase- 3 is a primary executioner that catalyzes the cleavage of PARP and actively induces apoptosis $[39,40]$. In this study, we found that PVE could downregulate PNCA expression, thereby decreasing the synthesis of caspase- 3 and Bax, and inducing apoptosis. The expression levels of PCNA, survivin, caspase-3, $\mathrm{Bcl}-2$, and $\mathrm{Bax}$ are related to the mitochondriamediated apoptotic pathway. The potential apoptotic mechanism of PVE-treated UM is PVE downregulation of PCNA, survivin and Bcl-2 expression and PVE upregulation of caspase- 3 and Bax expression through the mitochondria-mediated apoptotic pathway.

\section{Conclusions}

PVE has marked anti-UM activity and is safe and nontoxic. PVE can be used as an ideal candidate drug to treat UM. The potential mechanism, by which PVE inhibits tumor cell proliferation in UM, is through decreases in the contents of estrogen and progesterone and downregulation of ER and PR expression through the estrogen signaling pathway. The potential apoptotic mechanism of PVE-treated UM is PVE downregulation of PCNA, survivin and Bcl-2 expression and PVE upregulation of caspase- 3 and Bax expression through the mitochondria-mediated apoptotic pathway.

\begin{abstract}
Abbreviations
UM: Uterine Myoma; PVE: Extract of Prunella vulgaris L.; HUSMCs: Human Uterine Smooth Muscle Cells; HUMCs: Human Uterine Myoma Cells; MTT: $3-$ (4,5-Dimethylthiazol-2-yl)-2,5-Diphenyltetrazolium Bromide;

DMEM: Dulbecco's Modified Eagle Medium; PBS: Phosphate-Buffered Saline; GLC: Gong Liu-Qing Capsule; ELISA: Enzyme-Linked Immunosorbent Assay; HE: Hematoxylin and Eosin Staining; ER-a: Estrogen Receptor Alpha; ER$\beta$ : Estrogen Receptor Beta; PR: Progesterone Receptor; IHC: Immunohistochemistry.
\end{abstract}

\section{Acknowledgments}

Not applicable.

\begin{abstract}
Authors' contributions
Conceived and designed the study: LML, QZH, DFL. Performed the study: YL, CY, JT. Analyzed the data: YL, YC, CL, ZMZ, BHX, YML. Wrote the paper: YL and $Y C$. All authors read and approved the final manuscript.
\end{abstract}

\section{Funding}

This work was supported by the National Key R\&D Program "Research on Modernization of Traditional Chinese Medicine" of China (2017YFC1701900), Hunan Provincial Education Department Excellent Youth Fund (17B198) and the Natural Science Foundation of Hunan Province (2017JJ4045, 2017JJ1023, 2019JJ50449). First-class Discipline Project on Chinese Pharmacology of Hunan University of Chinese Medicine (2018-3). Changsha Science and technology Fund (kq1804027, kq1907139). The founder (Li-mei Lin) conceived and designed the study. The founder (Bo-hou Xia) analyzed the data.

Availability of data and materials

All of the data analyzed in this study is included in this article.

\section{Ethics approval and consent to participate}

All animal treatments and experiments were approved by the Animal Care and Use Committee of the University of Hunan University of Chinese Medicine, Changsha, China (SCXK (Xiang) 2016-0002).

Consent for publication

Not applicable.

Competing interests

All the authors declare that they have no competing interests.

\section{Author details}

${ }^{1}$ Key Laboratory for Quality Evaluation of Bulk Herbs of Hunan Province, College of Pharmacy, Hunan University of Chinese Medicine, No.300 Xueshi Road, Changsha 410208, People's Republic of China. ${ }^{2}$ China Institute of Chinese Materia Medica, China Academy of Chinese Medical Sciences, Beijing 100700, People's Republic of China. ${ }^{3}$ Hunan Province Cooperative Innovation Center for Molecular Target New Drug Study, School of Pharmacy and Life Science, University of South China, Hengyang 421001, People's Republic of China. 
Received: 15 September 2019 Accepted: 10 June 2020

Published online: 18 June 2020

\section{References}

1. Myers ER, Barber MD, Gustilo-Ashby T, Couchman G, Matchar DB, Mccrory DC. Management of uterine leiomyomata: what do we really know? Obstet Gynecol. 2002;100:8-17.

2. Chuang TD. Regulation of cell cycle regulatory proteins by micro RNAs in uterine leiomyoma. Reprod Sci. 2019;2:1-9.

3. Rein MS, Barbieri RL, Friedman AJ. Progesterone: a critical role in the pathogenesis of uterine myomas. Am J Obstet Gynecol. 1995;172:14-8.

4. Rizzello A, Franck M, Pellegrino M, Nuccio FD, Simeone P, Fiore G, et al. A proteomic analysis of human uterine myoma. Curr Protein Pept Sc. 2016;17:1-8.

5. Islam MS, Protic O, Stortoni P, Grechi G, Lamama P, Petraglia F, Castellucci M, Ciarmela P. Complex networks of multiple factors in the pathogenesis of uterine leiomyoma. Fertil Steril. 2013;100:178-93.

6. Maruo T, Ohara N, Wang J, Matsuo H. Sex steroidal regulation of uterine leiomyoma growth and apoptosis. Hum Reprod Update. 2004;10:207-20.

7. Ciarmela P, Islam MS, Reis FM, Gray PC, Bloise E, Petraglia F, Vale W, Castellucci M. Growth factors and myometrium: biological uterine fibroid and possible clinical implications. Hum Reprod Update. 2011;17:772-90.

8. Halder SK, Sharan C, Al-Hendy A. 1,25-dihydroxyvitamin d3 treatment shrinks uterine leiomyoma tumors in the eker rat model. Biol Reprod. 2012; 86:116.

9. Kastratovic T, Arsenijevic S, Matovic Z, Mitrovic M, Nikolić I, Milosavljević ZM, Crossed DS. Methotrexate and myotrexate induce apoptosis in human myoma fibroblasts (t hes cell line) via mitochondrial pathway. Acta Poloniae Pharmaceutica. 2015;72:455-64

10. Basu A, Haldar S. The relationship between Bcl-2, Bax and p53 (consequences for cell cycle progression and cell death). Mol Hum Reprod. 1998:4:1099-109.

11. Chen W, Ohara N, Wang J, Xu Q, Liu J, Morikawa A, Sasaki H, Yoshida S, Demanno DA, Chwaliisz K, Maruo T. A novel selective progesterone receptor modulator asoprisnil (j867) inhibits proliferation and induces apoptosis in cultured human uterine leiomyoma cells in the absence of comparable effects on myometrial cells. J Clin Endocr Metab. 2006;91: 1296-304.

12. Duhan N. Current and emerging treatments for uterine myoma - an update. Int J Women's Health. 2011;3:231-41.

13. Tu X, Huang G, Tan S. Chinese herbal medicine for dysfunctional uterine bleeding: a meta-analysis. Evid Based Complement Alternat Med. 2009;6:99-105

14. Rasool R, Ganai BA, Akbar S, Kamili AN. Phytochemical screening of Prunella Vulgaris L.- an important medicinal plant of Kashmir. Pak J Pharm Sci. 2014; 23:399-402.

15. Zhang M, Hwang E, Lin P, Gao W, Ngo HTT, Yi TH. Prunella vulgaris L. exerts a protective effect against extrinsic aging via NF-KB, MAPKs, AP-1, and TGF$\beta /$ Smad signaling pathways in UVB-aged normal human dermal fibroblasts. Rejuv Res. 2018;21:313-22.

16. Yin DT, Lei M, Xu JH, Li HQ, Wang YF, Liu Z, Ma RS, Yu K, Li XH. The Chinese herb Prunella vulgaris promotes apoptosis in human well-differentiated thyroid carcinoma cells via the B-cell lymphoma-2/Bcl-2-associated X protein/caspase-3 signaling pathway. Oncology Lett. 2017;14:1309-14.

17. Zaka M, Sehgal SA, Shafique S, Abbasi BH. Comparative in silico analyses of Cannabis sativa, Prunella vulgaris and Withania somnifera compounds elucidating the medicinal properties against rheumatoid arthritis. J Mol Graph Model. 2017;74:296-304.

18. Rana AD, Violet K, Fatma UA. Evaluation of the volatile oil composition and antiproliferative activity of Laurus nobilis L. (Lauraceae) on breast cancer cell line. Models Rec Nat Prod. 2014;8:136-47.

19. Yashika B, Vinay KG. Anticancer activity of essential oils: a review. J Sci food agr. 2013;93:3643-52.

20. Kim HI, Quan FS, Kim JE, Lee NR, Kim HJ, Jo SJ, Lee CM, Jang DS, Inn KS. Inhibition of estrogen signaling through depletion of estrogen receptor alpha by ursolic acid and betulinic acid from Prunella vulgaris var. lilacina. Biochem Biophys Res Commun. 2014;451:282-7.

21. Collins NH, Lessey EC, Dusell CD, McDonnell D, Fowler L, Palomino WA, Illera MJ, Yu XZ, Mo B, Houwing AM, Lessey BA. Characterization of antiestrogenic activity of the Chinese herb, prunella vulgaris, using in vitro and in vivo (mouse Xenograft) models. Biol Reprod. 2009;80:375-83.
22. Allouche Y, Warleta F, Campos M, Sánchez-Quesada C, Uceda M, Beltrán G Gaforio JJ. Antioxidant, antiproliferative, and pro-apoptotic capacities of pentacyclic triterpenes found in the skin of olives on MCF-7 human breast cance cells and their effects on DNA damage. J Agr Food Chem. 2011;59:121-3.

23. Aribi A, Gery S, Lee DH, Thoennissen NH, Thoennissen GB, Alvarez R, Ho Q, Lee K, Doan NB, Chan KT, Toh M, Said JW, Koeffler HP. The triterpenoid cucurbitacin B augments the antiproliferative activity of chemotherapy in human breast cancer. Int J Cancer. 2013;132:2730-7.

24. Shang D, Li Y, Wang C, Wang X, Yu Z, Fu X. A novel polysaccharide from seenriched Ganoderma lucidum induces apoptosis of human breast cancer cells. Oncol Rep. 2011:25:267-72.

25. Chen YY. The effect of Gongliuqing capsule on the serum levels of IL-22, TNF-a and sex hormone in the treatment of hysteromyoma. Chin J Ration Drug Use. 2017;14:11-3.

26. Koivisto KR, Leminen A, Heikinheimo O. Mifepristone as treatment of recurrent progesterone receptor-positive uterine leiomyosarcoma. Obstet Gynecol. 2007;109:512-4

27. Ju Y, Xiao B. Chemical constituents of Cyperus rotundus $L$ and their inhibitory effects on uterine fibroids. Afr Heal Sci. 2017;16:1000.

28. Jänicke RU, Sprengart ML, Wati MR, Porter AG. Caspase-3 is required for DNA fragmentation and morphological changes associated with apoptosis. J Biol Chem. 1998:273:9357-60.

29. Sherr CJ. Cancer cell cycles. Science. 1996;274:1672-7.

30. Alenzi FQ. Links between apoptosis, proliferation and the cell cycle. $\mathrm{Br}$ J Biomed Sci. 2004;61:99-102.

31. Shime H, Kariya M, Orii A, Momma C, Kanamori T, Fukuhara K, Kusakari T, Tsuruta Y, Takakura K, Nikaido T, Fujii S. Tranilast inhibits the proliferation of uterine leiomyoma cells in vitro through G1 arrest associated with the induction of p21 waf1 and p53. J Clin Endocr Metab. 2002;87:5610-7.

32. Horiuchi S, Kato K, Suga S, Takahashi A, Ueoka Y, Arima T, Nishida Jl, Hachisuga T, Hawarabayashi T. Expression of progesterone receptor B is associated with G0/G1 arrest of the cell cycle and growth inhibition in NIH3T3 cells. Exp Cell Res. 2005:305:233-43.

33. Nishida M, Nasu K, Ueda T, Yuge A, Narahara H. $\beta$-Hydroxyisovalerylshikonin induces apoptosis and G0/G1 cell-cycle arrest of endometriotic stromal cells: a preliminary in vitro study. Hum Reprod. 2006;21:2850-6.

34. Okolo S. Incidence, aetiology and epidemiology of uterine fibroids. Best Pract Res Clin Obstet Gynaecol. 2008;22:571-88.

35. Wang L, Huang H, Liu D, Fang SF, Xian Y, Zhou JY, Zuo Y, Wang F, Huang O, He M. Evaluation of 14-3-3 protein family levels and associated receptor expression of estrogen and progesterone in human uterine leiomyomas. Gynecol Endocrinol. 2012;28:665-8.

36. Hall PA, Levison DA, Woods AL, Yu CC, Kellock DB, Watkins JA, Barnes DM, Gillett CE, Camplejohn R, Dover R. Proliferating cell nuclear antigen (PCNA) immunolocalization in paraffin sections: an index of cell proliferation with evidence of deregulated expression in some neoplasms. J Pathol. 1990;162: 285-94.

37. Jang $\mathrm{JH}$, Surh $\mathrm{YJ}$. BCl-2 protects against Abeta(25-35)-induced oxidative PC12 cell death by potentiation of antioxidant capacity. Biochem Biophys Res Commun. 2004;320:880-6.

38. Yang E, Zha JP, Jockel J, Boise LH, Thormpson CB, Korsmeyer SJ. Bad, a heterodimeric part-ner for $\mathrm{BCl}-\mathrm{XL}$ and $\mathrm{BCl}-2$, displaces Bax and promotescell death. Cell. 1995;80:285-91.

39. Brentnall M, Rodriguez-Menocal L, De Guevara RL, Cepero E, Boise LH. Caspase-9, caspase-3 and caspase-7 have distinct roles during intrinsic apoptosis. BMC Cell Biol. 2013;14:14-32.

40. Boulares AH, Yakovlev AG, Ivanova V, Stoica BA, Wang G, Iyer S, Smulson M. Role of poly (ADP-ribose) polymerase (PARP) cleavage in apoptosis caspase 3-resistant PARP mutant increases rates of apoptosis in transfected cells. J Biol Chem. 1999;274:22932-40

\section{Publisher's Note}

Springer Nature remains neutral with regard to jurisdictional claims in published maps and institutional affiliations. 